\title{
A MAGYARORSZÁGI VASÚTHÁLÓZAT REDUNDANCIÁJÁT BIZTOSÍTÓ VONALSZAKASZOK
}

\section{THE LINE SECTIONS THAT PROVIDE REDUNDANCY TO THE RAILWAY NETWORK OF HUNGARY}

\author{
TÓTH Bence \\ (ORCID: 0000-0003-3958-187X) \\ toth.bence@uni-nke.hu
}

\begin{abstract}
Absztrakt
Egy hálózat zavarállóságát jól jellemzi, hogy szükség esetén rendelkezésre állnak-e megfelelő kapacitású kerülőutak. Ezen kerülőutak meghatározásához a magyarországi vasúthálózatot egy élsúlyzott irányitott gráffal modelleztem. Az egyes vonalszakaszok sérülése esetén a hálózat forgalmának elterelhetôségét az ún. redundanciaindexszel jellemeztem.

Az eredmények azt mutatják, hogy a magyarországi vasúthálózatban megvannak azok az útvonalak, melyek elégséges tartalék kapacitást hordozhatnának a zavarok kezelésére. Ezek a vonalszakaszok azonban többségükben egyvágányúak, nem villamositottak és a megengedett sebesség rajtuk is igen alacsony. Ezért a hálózat jelen állapotában nem lenne képes kezelni a nagy forgalmú fövonalak sérüléseit. A cikkben bemutatom, mely vasútvonalak célzott fejlesztésével lenne jelentösen csökkenthetö a hálózat zavarérzékenysége.
\end{abstract}

Kulcsszavak: kritikus infrastruktúra, vasúthálózat, redundancia, gráfelmélet

\begin{abstract}
The resilience of a network against disruptions can be described well with the presence of detours with sufficient capacity. To determine these detours, the railway network of Hungary was modelled by a weighted directed graph. The measure describing the rerouting alternatives was the so-called redundancy index.

The results show that there are possible routes which could provide sufficient capacity to handle the traffic in the case of disruptions. However, these line sections are mostly singletracked, not electrified and their line speed is very low. Therefore, the network, in its present state could not handle the disruptions of main lines with high traffic. It is shown in the paper which lines should be developed in order to increase the resilience of the network.
\end{abstract}

Keywords: critical infrastructure, railway network, redundancy, graph theory 


\section{BEVEZETÉS}

Európa újra elkezdett a vasút felé fordulni. Az Európai Bizottság 2011-ben célul tüzte ki, hogy 2030-ig a 300 km-t meghaladó közúti árufuvarozás 30\%-át, 2050-ig pedig 50\%-át más közlekedési módokra, többek között vasútra terelje. Ebben Magyarországnak kiemelt szerep juthat, hiszen a Kelet- és Dél-Európa felé tartó TEN-T folyosók országunkon haladnak át, illetve Oroszország felé is fontos vasúti kapcsolattal rendelkezünk.

A növekvő forgalom azonban veszélyeket is rejt magában. Bizonyos rendszerelemek sérülése nemcsak komoly költségnövekedést, hanem akár a teljes hálózat megbénulását is eredményezheti. Ilyen például a budapesti Összekötő vasúti híd, a magyarországi vasúthálózat legkritikusabb eleme, melynek legkisebb zavarára is az egész hálózat érzékenyen reagál [1]. Éppen ezért fegyveres őrök védik, engedély nélkül tilos rajta az átjárás.

De nem csak az ilyen, közvetlenül is veszélyeztetetettet mütárgyakat kell védeni, fel kell készülni a lehetséges zavarok kezelésére is. A Ferencváros és Kelenföld állomások közti mütárgyakat és a nyílt pályát (bár igaz, hogy magas töltésen fut) egyáltalán nem védik. Pedig itt is bekövetkezhet az állomásközt hasonlóan megzavaró esemény, hiszen nem csak általában a vasúti közlekedés terrorfenyegetettsége magas [2], hanem a nyílt vonali terrortámadások is egyre gyakoribbá válnak [3]. Ezek a támadások ,a vasúti (...) hálózat mütárgyainak rombolását összekapcsolják a jármüvek ellen elkövetett akciókkal" is, melyekkel hosszabb-rövidebb időre megbéníthatják egy-egy régió, országrész, vagy egy egész ország forgalmát is és a megrongált hálózati elemek időleges kiesése azok földrajzi elhelyezkedésétől függően akadályozhatja a nemzetközi forgalom folyamatos fenntartását is [3].

A hálózat egy pontjának sérülése esetén az is elvárt lenne, hogy legyen „viszonylag rövid időn belül (a sérülés nagyságától függően 1-3 nap) helyreállítható a vasúti közlekedési rendszer müködőképessége, vagy aktiválhatók a szükséges helyettesítő kapacitások.” [5] Felmerülhet a szomszédos országokon keresztül vezető kerülöutak igénybevétele, ez azonban csak részben megoldás [6]. Bár a Dunán és a Tiszán jelenleg összesen 16 vasúti átkelési pont van [6], ezek töredéke alkalmas csak a nemzetközi teherforgalom lebonyolítására. Emellett a szükséghelyzeti átkelésekhez vezető szárnyvonalakat nem tartották karban, nagy részük el lett bontva [7] és ezek pótlására az Összekötő vasúti hídra tervezett harmadik vágány sem megoldás, hiszen ez a fejlesztés csak az állomásköz létező mütárgyainak áteresztőképességét növeli csak meg, valódi alternatív útvonalat nem biztosít [6].

Célom tehát azonosítani a magyarországi vasúthálózat azon vonalszakaszait, melyek az egyes hálózati elemek sérülésekor a leggyakrabban részei a kerülőutaknak. Ezek ugyanis azok a vonalszakaszok, melyek normál üzemben esetleg csak kis forgalmat bonyolítanak, a zavarkezelésben azonban lényeges szerepet kellene betölteniük. Éppen ezért ezeknek nem csak a védelméröl, hanem a karbantartásáról, fejlesztéséről is gondoskodni kell. Mivel „a mellékvonali forgalom jelentős csökkenése a hálózati infrastruktúra leépüléséhez vezet, amelynek következtében a felszámolások elötérbe kerülnek, csökkentve ezzel az alternatívaként igénybe vehető hálózatokat" [4; 44. o.], tudatosan kell tenni a meglevő hálózat zavar esetén is elégséges müködőképességéért.

A következőkben először bemutatok egy matematikai modellt, melynek segítségével ezek a vonalszakaszok azonosítottam, majd a kapott eredmények alapján javaslatokat fogalmazok meg a magyarországi vasúthálózat lehetséges fejlesztési irányaival kapcsolatban.

\section{A MAGYARORSZÁGI VASÚTHÁLÓZAT GRÁFMODELLJE}

A magyarországi vasúthálózat modellezésére egy élsúlyozott irányított gráfot $[8 ; 36.0$. használok [9],[10],[11] melyben az egyes csúcsok az állomásokat, az élek pedig a közöttük levő vasútvonal-szakaszokat reprezentálják. A modellben nem szerepelnek nyílt vonali megállóhelyek, csak állomások, ahol lehetőség van irányváltásra. Ezeket sem mind tartalmazza 
a modell, csak az elágazó- és csatlakozó állomásokat [12], a zsákvonalak végpontjait, a határátmeneteket, valamint a határátmeneteket közvetlenül megelőző állomásokat. Mivel nem minden állomás szerepel a modellben, az ,állomásköz” kifejezést a gráfelméleti „él” értelemben használom két, állomást reprezentáló csúcs között. Egy „él” tehát sok esetben több egymás utáni valódi állomásközt jelent az adott vonalszakasz közbenső állomásai nélkül.

Az egyes élek súlyai vagy az állomásközök kilométerben mért hosszai voltak, vagy a menetidök percben az egyes állomásközökre érvényes maximális engedélyezett sebesség alapján számolva. Az egyes állomástávolságok fő forrása a Vasúti Pályakapacitás-elosztó Kft. (VPE Kft.) weblapján [13] elérhető adatok voltak. Néhány, itt nem szereplő iparvágány hosszát a vonatkozó kormányrendelet [14] alapján építettem be a modellbe. Az állomások közötti menetidöket ezen távolságadatok és az engedélyezettsebesség-értékek [13],[15],[16] alapján határoztam meg. Ez azt is jelenti, hogy ezek a menetidő-értékek csak egy alsó korlátot jelentenek, melyek még a tiszta menetidőnél is alacsonyabbak. Ahol kisebb engedélyezettsebesség-érték vonatkozott a mozdonnyal továbbított vagy a nagyobb tengelyterhelésü szerelvényekre, ott ezt az alacsonyabb sebességértéket vettem figyelembe a számolásoknál [17]. Azonban jelenleg kiépítési sebességgel csak a magyarországi vasúti pályáknak kevesebb mint kétharmadán lehet közlekedni [18],[19],[20], bár a TEN-T hálózati elemeken [21] elvárás az EU részéről a legalább 160 kilométer per órás sebesség [22],[23].

Az állomási irányváltásokhoz (ahol erre szükség volt) figyelembe vettem az ehhez szükséges menetidö-növekedést: minden alkalommal egy fix értéket, 15 percet [24; 234. o.],[25] adtam hozzá a menetidőhöz. Ennek érdekében minden állomás (pontosabban minden elágazás, a deltavágányok egyes kitérői is) négy csúcsként volt reprezentálva a gráfban. Például Győr esetében (lásd 1. ábra) annak kezdő- és végpontján is definiáltam egy-egy „érkező” és egy „,induló” csúcsot, melyekbe, illetve melyekből a szomszédos állomások megfelelő csúcsaiba, illetve csúcsaiból a gráf élei be-, illetve kifutnak. Az irányváltások 15 perces időigényét egyegy, az egyes állomások kezdőponti „érkező” és „,induló” csúcsa, illetve végponti „ékező” és „,induló” csúcsa közötti 15 perccel (vagy 0 kilométerrel) súlyozott éllel vettem figyelembe. Emellett szükséges volt még a gráf egyes éleinek irányítása is [8; 21-22. o.], hogy az „induló” csúcsok biztosan induló csúcsok, az „érkezők” pedig érkezők legyenek minden menetvonal esetében és ne legyen lehetséges irányváltás úgy, hogy a menetvonal nem halad át a megfelelö 15 perc súlyú élen. Ugyanezért szükséges volt az állomásközöket éleinek megduplázása is: egy állomásköz egyik irányított éle az egyik szomszédos állomásnak az adott állomásközhöz tartozó „,induló” csúcsából mutat a másik szomszédos állomás megfelelő „érkező” csúcsába és fordítva. Egy „,induló”, illetve egy „érkező” csúcsot természetesen bármennyi, másik állomáshoz tartozó „érkező”, illetve „induló csúccsal összeköthet egy-egy megfelelően irányított él.

Mivel az állomások belső vágányzatát nem vettem figyelembe, az állomásokon való áthaladáshoz sem távolság-, sem menetidőnövekményt nem rendeltem, azaz az állomások megfelelő „,érkező” és „induló” csúcsait összekötő „belső” élek súlya 0 perc és $0 \mathrm{~km}$ volt. Hasonlóan, az irányváltáshoz sem rendeltem menetvonalhossz-növekményt, azaz az azonos oldali „érkező” és ,induló” csúcsokat összekötő él súlya $0 \mathrm{~km}$ volt. Deltavágányon önmagában (azaz állomásra való behaladás nélkül) irányváltás nem lehetséges, csak áthaladás, ezért ezek esetében, bár szintén négy csúccsal reprezentáltam őket a gráfban, csak 0 perc vagy 0 km súlyú áthaladó éleket rendeltem hozzájuk, irányváltást lehetővé tevőket nem. Fejállomások reprezentálásához elegendő két csúcs, köztük egy 15 perc vagy 0 km súlyú éllel. 


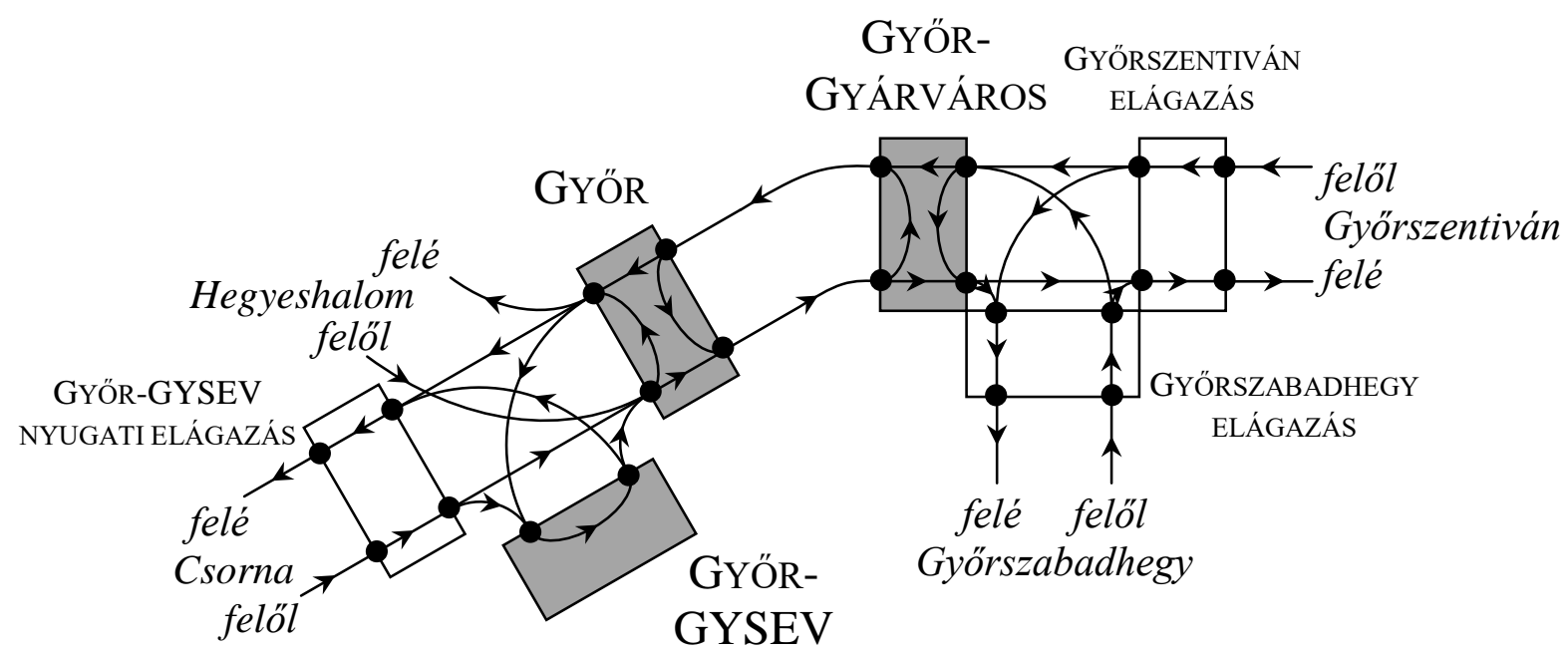

1. ábra A magyarországi vasúthálózat gráfmodelljének felépítési elvei Győr és néhány környező állomás (szürke) és deltavágány (fehér) példáján szemléltetve. [saját szerkesztés]

A számolások alapjául szolgáló gráfban összesen 1136 csúcs szerepelt, melyek 291 állomást és 26 deltavágányt reprezentálnak négy (fejállomások esetén két) csúccsal. A gráf összesen 1808 élből állt, melyből 732 él (366 él-pár) szomszédos állomások közti viszonylatot írt le, míg a többi az állomások „,belső szerkezetét” és a deltavágányok kapcsolatait. Mindegyik élhez kés súly tartozott; a számítások során természetesen egyszerre csak az egyiket rendeltem hozzá az élekhez. Az azonos állomásközhöz tartozó két ellentétesen irányított él súlya minden esetben megegyezett.

Jelöljük a zavarmentes, menetidö-értékekkel súlyozott gráfot $G_{t}^{0}=\left(V, E, W_{t}\right)$-lal, a távolságokkal súlyozottat pedig $G_{\ell}^{0}=\left(V, E, W_{\ell}\right)$-lal, ahol $V$ a csúcsok, $E$ az élek halmaza, $W_{t}$ és $W_{\ell}$ pedig a menetidö- és távolságsúlyok halmazai. Ekkor az egyes élekhez tartozó $w_{t} \in W_{t}$ és $w_{\ell} \in W_{\ell}$ súlyok az egyes élek $w_{t}(e)$, illetve $w_{\ell}(e)$ függvényeiként is felfoghatóak, ahol $e \in E$.

\section{SZÁMÍTÓGÉPES MEGVALÓSÍTÁS}

Az összes bemutatott számolás és a kapott eredmények vizualizálása is az $R$ programozási nyelv és környezetben [26] történt az igraph csomag [27] segítségével (melyet Csárdi Gábor és Nepusz Tamás fejlesztett ki).

\section{Legrövidebbút-keresés}

Mivel mind a távolság-, mind a menetidőértékek (a súlyok) pozitív valós számok, továbbá a gráf is viszonylag kis méretü, ezért két állomás között a legrövidebb út meghatározására a legcélszerübb a Dijkstra-algoritmus [28],[8; 37. o.] használata volt. A módszer az igraph csomagban a distances() függvényben van implementálva és kizárólag pozitív élsúlyok esetében ez a függvény alapbeállítása is.

Lefuttatva a legrövidebbút-keresést minden $\langle a, b\rangle$ állomáspárra (ahol $a \neq b$ ) a menetidö- és a távolságsúlyokkal is, kétszer 42195 értéket kapunk, mely számértéket jelöljünk $N^{0}$-lal. Jelöljük továbbá a $G_{t}^{0}$ gráfon az $a$ és a $b$ állomás közötti leggyorsabb út időtartamát $t_{a b}^{0}$-vel, a $G_{\ell}^{0}$ gráfon a közöttük létező legrövidebb út hosszát pedig $\ell_{a b}^{0}$-vel. 


\section{Állomásközök zavara}

Zavar alatt egy állomásköz hálózatból való teljes kizárását fogom érteni, azaz az adott állomásköz forgalom számára való teljes elérhetetlenségét. Jelöljük a zavart állomásközt reprezentáló gráfbeli élpárt $e$-vel $(e \subseteq E)$. Az $e$ élpárt nem tartalmazó, időtartamokkal súlyozott gráfot jelöljük $G_{t}^{e}=\left(V, E \backslash D, W_{t}^{e}\right)$-vel, az e élpárt nem tartalmazó, távolságértékekkel súlyozott gráfot pedig $G_{\ell}^{e}=\left(V, E \backslash D, W_{\ell}^{e}\right)$-vel, ahol $W_{t}^{e}$ és $W_{\ell}^{e}$ a megmaradó élekhez tartozó súlyok halmazai: $W_{t}^{e} \subseteq W, W_{\ell}^{e} \subseteq W$ és az egyes $w_{t}^{e}(f)$ és $w_{\ell}^{e}(f)$ idö- és távolságsúlyokra pedig igaz, hogy $w_{t}^{e} \in W_{t}^{e}, w_{\ell}^{e} \in W_{\ell}^{e}$ és $f \in(E \backslash e)$.

\section{A REDUNDANCIA}

Egy állomásköz pótolhatatlan, ha sérülése esetén a hálózatban lesznek egymás számára elérhetetlen állomások, azaz nem létezik köztük (akármilyen hosszúságú) kerülőút. Ezen, úgynevezett zsákvonalakhoz tehát egyik állomásköz sem ad, nem tud adni redundanciát, azaz nem kiválthatóak alternatív útvonallal.

Ha egy menetvonal a zavarmentes hálózatban áthalad egy zsákvonal egy $u$ állomásközén, akkor két eset lehetséges. Vagy a zavart hálózatban is keresztülhalad az $u$ állomásközön, és ebben az esetben nincs értelme a redundanciának, hiszen $u$ nem sérült. Vagy a sérült $v$ állomásköz az adott zsákvonal egy másik szakasza, de ebben az esetben már nincs menetvonal, hiszen a célállomás elérhetetlen lett a hálózat legalább egy másik állomása részére és nincs a redundanciát biztosítani képes útvonal, így ez az eset is érdektelen számunkra.

\section{A hálózatrobusztussági index}

Hálózatok rendszerszintű zavarállóságának kvantitatív jellemzésére gyakran használt globális mérőszám az úgynevezett hálózatrobusztussági index (Network Robustness Index, NRI), melyet D. M. Scott és társszerzői [29] vezettek be 2006-ban megjelent cikkükben. Az index a hálózatot reprezentáló gráf minden éléhez hozzárendel egy, a gráf súlyozásától függő számértéket, melyek alapján az egyes élek fontosság szerint rendezhetőek.

A gráf egy tetszőleges $u$ éléhez tartozó hálózatrobusztussági index kiszámításához a zavarmentes hálózat összes lehetséges, menetvonal kezdő- és végpontjaként szolgáló állomáspár között határozzuk meg a legrövidebb út hosszát és ezeket az értékeket adjuk össze. A kapott összeget jelöljük $c$-vel.

Ezután távolítsuk el a gráfból az $u$ élt, melynek NRI értékére kíváncsiak vagyunk, és ismét határozzuk meg az összes állomáspár között a legrövidebb út hosszát és ezeket is adjuk össze. Ezt, a zavart hálózatra kapott az összeget jelöljük $c^{u}$-val. A hálózatrobusztussági index ezen két összeg különbsége, melyet jelöljünk $q^{u}$-val:

$$
q^{u}=c^{u}-c .
$$

A különbségképzés sorrendje azért a fenti, hogy a $q^{u}$ értékére pozitív szám adódjon, hiszen a legtöbb súlyozás (pl. távolság, idő, költség, stb.) esetében egy él eltávolítása a legrövidebb utak összsúlyait növeli (de legalábbis nem csökkenti). Ez elvégezhető minden $e$ élre, de akár több élre is, például az $u$ és a $v$ élekre:

$$
q^{u v}=c^{u v}-c
$$

A hálózatrobusztussági index egy adott állomáspárra vett $q_{a b}^{u}$ értéke (azaz amikor nem összegzünk ezekre) azt is megmutatja, hogy a két állomás közti legrövidebb út a zavarmentes hálózatban érinti-e az $u$ élt. Ha $q_{a b}^{u}=0$, azaz $c^{u}=c$, az azt jelenti, hogy az $u$ él nem része az $a$ és a $b$ állomások közti legrövidebb útnak sem a $G^{0}$, sem a $G^{u}$ gráfban. Ha $q_{a b}^{u}>0$, azaz $c^{u}>c$, 
az azt jelenti, hogy az $u$ él törlésének hatására megnőtt a legrövidebb út hossza az $u$ él törlésével kapott gráfban a zavarmentes gráfhoz képest, azaz a zavarmentes hálózatban az $u$ állomásköz része volt a legrövidebb útnak.

\section{A redundanciaindex}

A hálózatrobusztussági index tehát egy él törlése (azaz egy állomásköz teljes kizárása) által a teljes hálózaton okozott növekményt méri az adott súlyozás mellett. Egy adott $v$ élnek a hálózatot reprezentáló gráfból való törlése azonban azt is jelenti, hogy a zavarmentes hálózathoz képest a zavart hálózatban egyes állomáspárok közti legrövidebb utak pontos útvonala is változni fog. Tegyük fel például, hogy a $G^{0}$ gráfban a legrövidebb út nem haladt keresztül az $u$ élen, de a $G^{v}$ gráfban már igen. Mekkora további növekménnyel számolhatnánk, ha az $u$ élt is törölnénk a $G^{v}$ gráfból, azaz mennyi lenne hosszabb a legrövidebb út az $\langle a, b\rangle$ állomáspár között a $G^{u v}$ gráfban?

Arra vagyunk tehát kíváncsiak, hogy mekkora teljes növekményt okoz a $v$ él mellett az $u$ él törlése is azon állomáspárok közti legrövidebb útban, melyek a $G^{0}$ gráfban nem haladtak keresztül az $u$ élen, de a $G^{v}$ gráfban már igen. Ez a növekmény adja meg az $u$ élnek a $v$ élhez adott teljes redundanciáját. Azon legrövidebb utak, melyek sem a $G^{0}$, sem a $G^{v}$ hálózatban nem haladtak keresztül az $u$ élen, illetve melyeknek az mindkét hálózatban része volt, nem relevánsak, hiszen ezen utak nem érzékenyek az $u$ él törlésére.

Azon a legrövidebb utakkal foglalkozunk tehát, melyekre $q^{u}=0$. Az $r^{u v}$ redundanciaindexet a $G^{u v}$ gráfbeli legrövidebb út hosszának a $G^{v}$ gráfbeli értékéhez képesti növekményeként definiáljuk:

$$
r^{u v}=q^{u v}-q^{v}=\left(c^{u v}-c\right)-\left(c^{v}-c\right)=c^{u v}-c^{v} .
$$

Az összes olyan $v$ élre, mely nem azonos $u$-val, meghatározva $r^{u v}$ értékét és ezeket összegezve megkapjuk az $u$ él által a $v$ élekhez adott teljes redundanciát:

$$
r^{u}=\sum_{v} r^{u v}=\sum_{v}\left(q^{u v}-q^{v}\right)=\sum_{v}\left(c^{u v}-c^{v}\right)
$$

Ezt a definíciót Erik Jenelius alkotta meg 2010-es cikkében [30].

\section{Alkalmazás egyszeresen élösszefüggő gráfokra}

A redundanciaindex meghatározásának módjából látszik, hogy ha egy olyan élt törlünk, mely nélkül egy vagy több állomás elérhetetlen lesz a többi állomás számára a hálózatban, akkor mind a $q^{u}$, mind az $r^{u}$ értéke végtelenné válik. Az ilyen típusú gráfokat egyszeresen élösszefüggőnek nevezzük; a magyarországi vasúthálózatot leíró gráf is egyszeresen élösszefüggő. A $G^{0}$ gráf esetében egy él törlése esetén még nem túl sok esetben esik két részgráfra a hálózatunk, két él törlése esetén azonban már jelentősen csökken az értelmezhető eredmények száma. Ha az ilyen állomásközöket kihagyjuk a teljes vizsgálatból, akkor rendkívül kevés él marad a gráfban, melyekre tudunk számolni; míg ha csak az éppen aktuális számolásban végtelen eredményt adó éleket hagyjuk ki, akkor minden $v$ él esetében más-más éleket veszünk figyelembe, ami viszont az egyes $r^{u}$ értékek egymással való összehasonlítását teszi lehetetlenné.

Éppen ezért célszerű áttérni az egyes súlyok reciprokterébe: a két pont közötti legrövidebb út meghatározása után nem ezt, hanem a (kilométerben vagy percben mért) távolságérték reciprokát használjuk a további számolásokban. Emiatt a két tagot a v-re való szummázás mögött a (2) kifejezésben célszerü felcserélni, hogy a rendundanciaindex továbbra is pozitív legyen, hiszen a hosszabb utaknak a reciproktérben rövidebb értékek felelnek meg. 
Az egyes redundanciaindexeket a reciproktérben összegezve minden $v$ élre megkapjuk az egyes $u$ élek teljes redundanciáját:

$$
\begin{aligned}
& \sum_{v} r_{\ell}^{u v^{\prime}}=\sum_{v}\left(c_{\ell}^{v \prime}-c_{\ell}^{u v^{\prime}}\right)=\sum_{v}\left(\sum_{\langle a, b\rangle} \frac{1}{\ell_{a b}^{v}}-\sum_{\langle a, b\rangle} \frac{1}{\ell_{a b}^{u v}}\right) \\
& \sum_{v} r_{t}^{u v^{\prime}}=\sum_{v}\left(c_{t}^{v \prime}-c_{t}^{u v^{\prime}}\right)=\sum_{v}\left(\sum_{\langle a, b\rangle} \frac{1}{t_{a b}^{v}}-\sum_{\langle a, b\rangle} \frac{1}{t_{a b}^{u v}}\right) .
\end{aligned}
$$

Informatívabb azonban a zavarmentes hálózatbeli össz-menetvonalhosszra, illetve összmenetidőre normálni a kapott értékeket, azaz mindet leosztani $c$-vel:

$$
\begin{aligned}
& r_{\ell}^{u \prime}=\frac{\sum_{v} r_{\ell}^{u v \prime}}{c_{\ell}^{\prime}}=\frac{\sum_{v}\left(c_{\ell}^{v \prime}-c_{\ell}^{u v \prime}\right)}{c_{\ell}^{\prime}}=\frac{\sum_{v}\left(\sum_{\langle a, b\rangle} \frac{1}{\ell_{a b}^{v}}-\sum_{\langle a, b\rangle} \frac{1}{\ell_{a b}^{u v}}\right)}{\sum_{\langle a, b\rangle} \frac{1}{\ell_{a b}^{0}}}, \\
& r_{t}^{u \prime}=\frac{\sum_{v} r_{t}^{u v^{\prime} \prime}}{c_{t}^{\prime}}=\frac{\sum_{v}\left(c_{t}^{v \prime}-c_{t}^{u v \prime}\right)}{c_{t}^{\prime}}=\frac{\sum_{v}\left(\sum_{\langle a, b\rangle} \frac{1}{t_{a b}^{v}}-\sum_{\langle a, b\rangle} \frac{1}{t_{a b}^{u v}}\right)}{\sum_{\langle a, b\rangle} \frac{1}{t_{a b}^{0}}} .
\end{aligned}
$$

Az $r^{u}$ ' redundanciaindex tehát aszerint rangsorolja az éleket, hogy az egyes $v$ élek zavara esetén az $u$ él felé kerülö legrövidebb utak hossza összesen mennyire nőne meg a többi élhez viszonyítva, ha az $u$ él is kiesne a rendszerböl.

Egy adott gráfban számolt redundanciaértékek ugyanakkor a definícióból adódóan nem használhatóak fel különböző hálózatok egyes éleinek összehasonlítására, azok szigorúan csak egy hálózaton belül értelmezhetőek, ott is csak a többi él redundanciaértékéhez viszonyítva.

\section{Az inverz redundancia}

A (7)-(8) összefüggésekben nem a $v$, hanem az egyes $u$ állomásközökre végezve el a szummázást, azt kapjuk meg, hogy a $v$ állomásköz mekkora redundanciát kap a többi állomásköztől:

$$
\begin{aligned}
& \tilde{r}_{\ell}^{\nu \prime}=\frac{\sum u\left(\sum_{\langle a, b\rangle} \frac{1}{\ell_{a b}^{v}}-\sum_{\langle a, b\rangle} \frac{1}{\ell_{a b}^{u v}}\right)}{\sum_{\langle a, b\rangle} \frac{1}{\ell_{a b}^{0}}}, \\
& \tilde{r}_{t}^{\nu \prime}=\frac{\sum u\left(\sum_{\langle a, b\rangle} \frac{1}{t_{a b}^{v}}-\sum_{\langle a, b\rangle} \frac{1}{t_{a b}^{u v}}\right)}{\sum_{\langle a, b\rangle} \frac{1}{t_{a b}^{0}}}
\end{aligned}
$$

Ez annak a méröszáma, hogy a $v$ állomásköz zavara esetén mekkora növekményt okozna, ha a legrövidebb kerülöirányok egyes $u$ állomásközei szintén sérülnének és ezért egy még hosszabb kerülöútra terelödne az adott $a$ és $b$ állomás közötti forgalom. Vagyis azt mutatja meg, mekkora redundanciát igényel a $v$ állomásköz a sérülése esetén.

\section{A MAGYARORSZÁGI VASÚTHÁLÓZAT REDUNDANCIÁT BIZTOSÍTÓ ELEMEI}

Meghatározva a magyarországi vasúthálózat egyes elemeinek redundanciáját, beazonosíthatóak azok az állomásközök, melyek a többi vonalszakasz zavara esetében a leggyakrabban, illetve a legrövidebb kerülőutat biztosítják. 


\section{Minimális hosszúságú menetvonalak}

A $G_{\ell}^{0}$ gráf minden $u$ élére meghatározva az $r_{\ell}^{u \prime}$ index értékét a 2. ábrán látható eredményeket kapjuk.

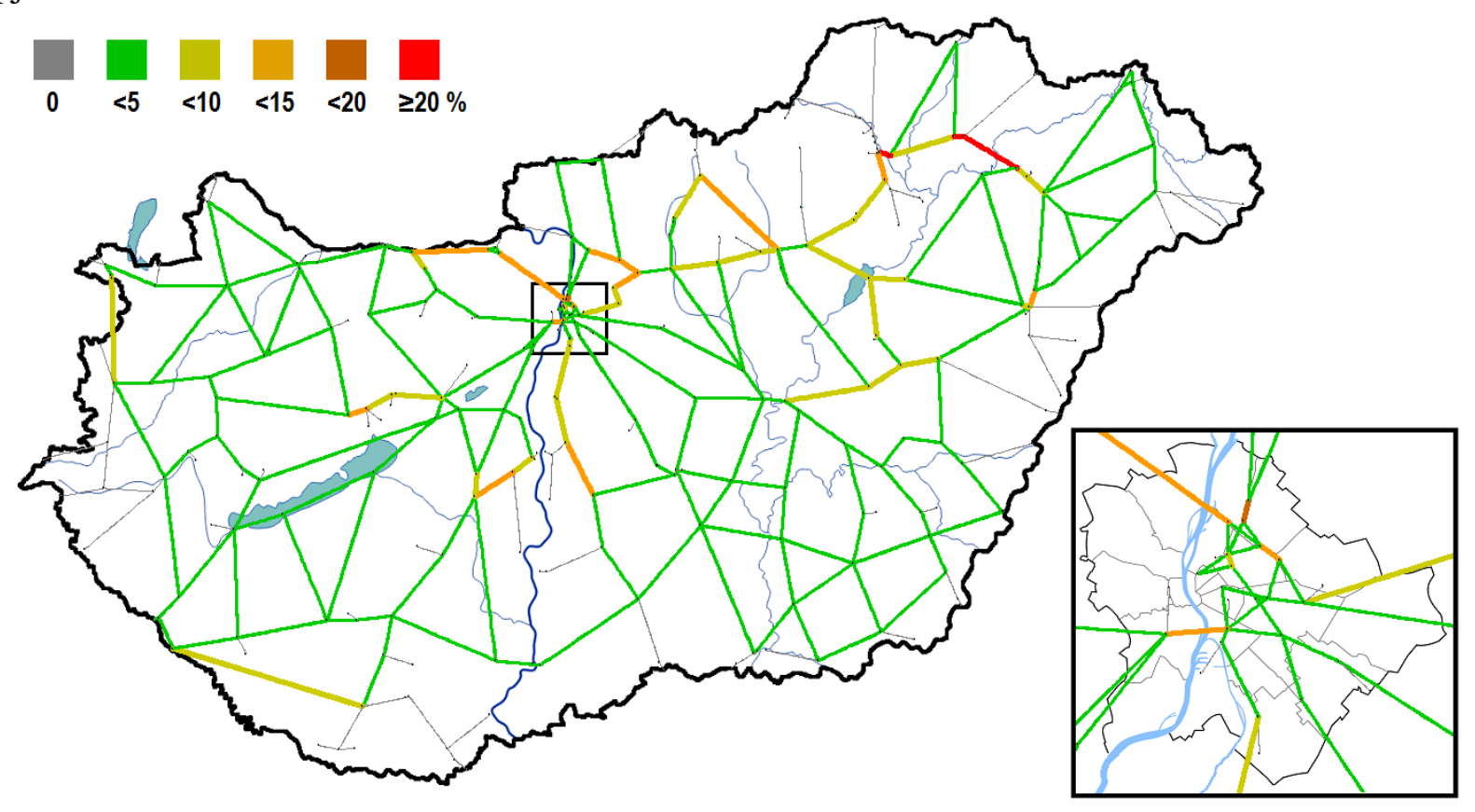

2. ábra A magyarországi vasúthálózat állomásközeinek redundanciaértékei minimális hosszúságú menetvonalak esetében [saját szerkesztés]

Azt eredmények azt mutatják, hogy a legnagyobb teljes redundanciája a 80-as vonalon fekvő (egyvágányú) Görögszállás-Mezőzombor vonalszakasznak van, értéke 32\%. Ez tehát az a vonalszakasz, melynek sérülése az ezt érintő kerülőutak hosszának legnagyobb arányú növekedését eredményezné. Ennek a vonalszakasznak a része a tokaji Tisza-híd is, mely, bár nem kiemelt forgalmú tiszai átkelőhely (szemben például a szolnoki Tisza-híddal), éppen a redundanciája miatt létfontosságú hálózati elem.

Szintén a 80-as vonal része a második és harmadik legnagyobb teljes redundanciájú állomásköz: Szerencs-Mezőzombor $\left(r_{\ell}^{\prime}=27 \%\right)$ és Felsőzsolca-Miskolc-Tiszai $\left(r_{\ell}^{\prime}=22 \%\right)$. A három legnagyobb teljes redundanciájú állomásköz tehát ugyanannak, a Miskolc-Nyíregyháza vonalszakasznak a része: ez teremti meg a kapcsolatot a jelentős teherforgalmat bonyolító Budapest-Debrecen-Nyíregyháza és a Budapest-Hatvan-Miskolc vonalak között. A 80-as vonal Miskolc és Budapest közötti, de főleg a 100-as vonal Nyíregyháza és Budapest közti, országhatár felöl érkező és arrafele tartó forgalmát az adott vonal zavara esetén egymás között ezen a vonalszakaszon legrövidebb és ezért legcélszerübb átterelni a másik fövonalra.

Jelentős, $14 \%$-os összredundanciájú a 2-es és a 4-es vonalak Angyalföld-Almásfüzitő közti szakasza, mely föleg az Összekötő vasúti hídon áthaladó menetvonalakhoz ad(hatna) redundanciát. „A két híd közt az átjárhatóság közvetve megoldható, így a redundancia - még a külföldi kerülőt figyelmen kívül hagyva is - adott" [31], ez azonban, föleg a 4-es vonal jelenlegi állapota miatt, csak elméleti lehetőség, hiszen bár ez az útvonal csak kicsivel hosszabb a Budapest-Tatabánya-Almásfüzitő útvonalnál, a pálya több paraméterben lényegesen rosszabb az 1-es fővonalnál: nem villamosított, egyvágányú és a pálya állapota miatt alacsony engedélyezett sebességü.

Meglepő lehet azonban az Aszód és Galgamácsa közti (egyvágányú, de villamosított) 78-as vasútvonal $13 \%$-os összredundanciája: a számolások alapján ez az irány eredeti funkciójával összhangban valóban hatékonyan tudja terelni a forgalmat, forgalomból való kiesése azonban jelentős kerülő megtételét teszi szükségessé. 
Szükséges ugyanakkor megjegyezni, hogy a pályák villamosítása veszélyeket is hordoz. Bár normál üzemben lényegesen előnyösebb a villamos vontatás a dízelnél, a felsővezetékek sérülése vagy az áramellátás zavara esetén ugyanazzal a helyzettel szembesülünk, mintha maga a pálya sérült volna, amennyiben nincs elegendő számú rendelkezésre álló dízelmozdony. Ezek rendszerből való kivonása azonban a villamosított vasútvonalak növekvő részarányával párhuzamosan egyre inkább elörehalad [4; 87. o.].

\section{Minimális menetidők}

A $G_{t}^{0}$ gráf minden $u$ élére meghatározva az $r_{t}^{u \prime}$ index értékét a 3. ábrán látható eredményeket kapjuk.

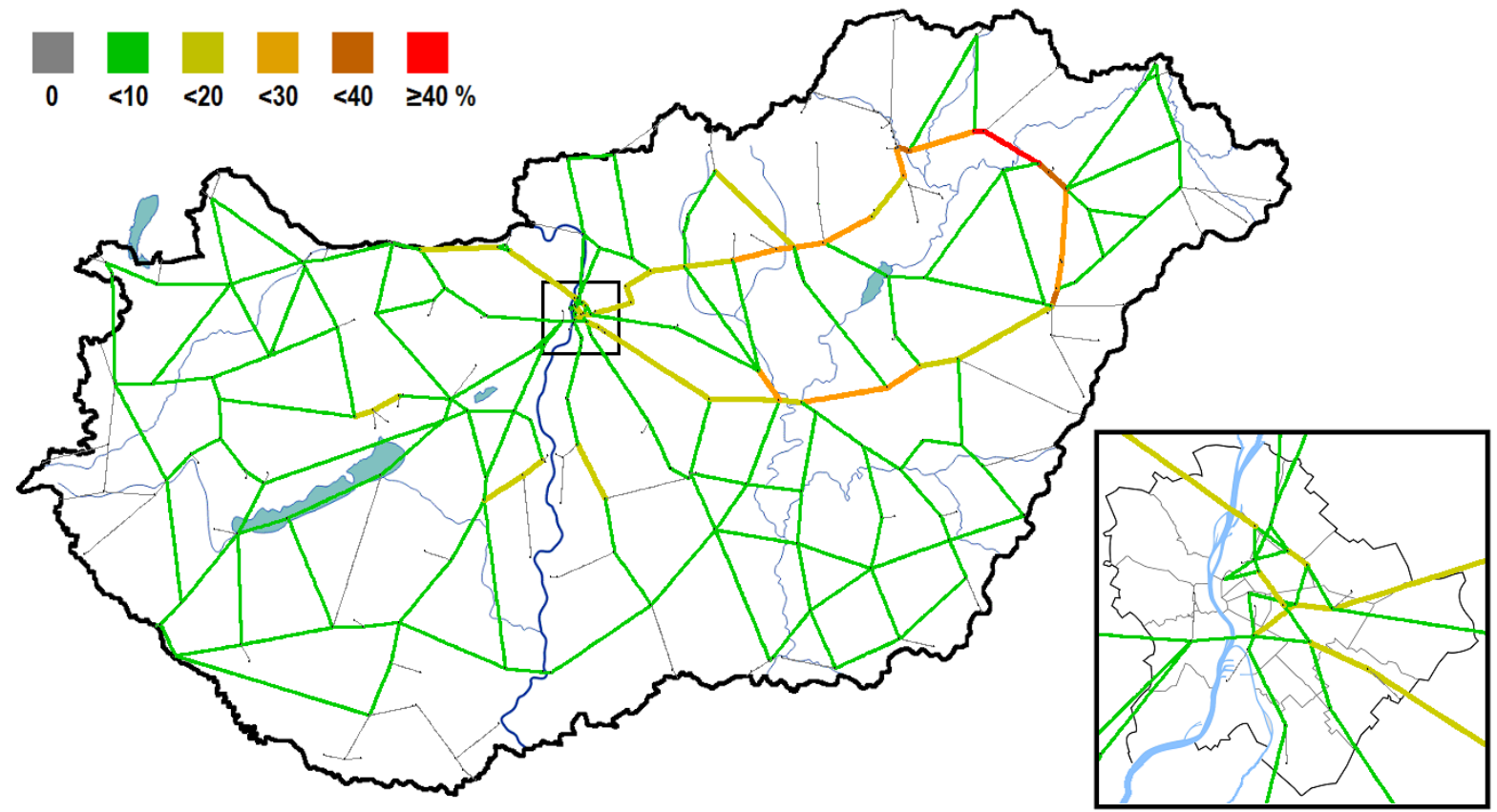

3. ábra A magyarországi vasúthálózat állomásközeinek redundanciaértékei minimális menetidejű menetvonalak esetében [saját szerkesztés]

A kapott eredmények a legjelentősebb vonal, a 80-as szempontjából hasonlóak a menetvonalhosszak esetéhez, ugyanis a legnagyobb redundanciát $\left(r_{t}^{\prime}=48 \%\right)$ a GörögszállásMezözombor állomásköz adja. A 80-as vonal szomszédos állomásközeinek redundanciaértékei sem sokkal kisebbek: a Mezőzombor-Szerencs állomásközre $r_{t}^{\prime}=42 \%$, a FelsőzsolcaMiskolc-Tiszai állomásközre $r_{t}^{\prime}=36 \%$, de a Görögszállás-Nyírtelek állomásközre is $r_{t}^{\prime}=31 \%$. A 80-as vonal Miskolc és Nyíregyháza közti része tehát fontos szerepet tölthet be, mint a nagy forgalmú 100-as és a 80-as vasútvonalak [20] közti kapcsolatot biztosító lehetséges kerülőút.

A Debrecen-Apafa állomásköz 32\%-os redundanciája annak szük keresztmetszet voltát jelzi: zavar esetén csak Tiszalök vagy Füzesabony felé lehet kerülni, mindkét irányban villamosítatlan pályán, egy vágányon. Elöbbi kilométerben fele olyan hosszú, de időben csak kb. $10 \%$-al gyorsabb.

A 2-es és a 4-es vonalak redundanciája menetidők szempontjából kevésbé jelentős a pusztán a távolságértékeken alapuló számoláshoz képest, de a 4-es vonal állapotát ismerve meglepő módon még mindig nem elhanyagolható. A 77-es és 78-as vonalak Aszód és Vácrátót közti szakaszának fejlesztésével mindkét útvonal az Összekötő vasúti híd reális alternatívájává lenne fejleszthetö.

Az Összekötő vasúti híd alacsony redundanciaértéke (3\%) azt jelenti, hogy azon menetvonalak terelése, melyek a zavarmentes hálózatban nem haladtak keresztül rajta, alternatív útvonal igénybevétele esetén sem befolyásolják lényegesen a hálózat müködését. A 
Dunán át nem áthaladó menetvonalak szempontjából lényegtelen, van-e híd, míg az Újpesti vasúti híd forgalmát jórészt csak a 2-es vonalon közlekedő vonatok adják, ezek viszont annyira kevesen vannak, hogy Baja felé történő terelésük (a rendkívül nagy menetidőnövekmény ellenére) nem befolyásolná érdemben a hálózat müködését. Vice versa: a zavarmentes hálózatban a bajai vasúti hídon áthaladó menetvonalak szempontjából gyakorlatilag mindegy, hogy az 1-es vagy a 2-es és a 4-es vonal felé kell-e kerülni.

\section{KÖVETKEZTETÉSEK}

A magyarországi vasúthálózat világviszonylatban is sürünek számít. Ennek előnyeit azonban csak megfelelően karban tartott infrastruktúrával, a megfelelő redundanciák biztosításával lehet kihasználni. Két pont között egy alternatív útvonal fenntartása nem felesleges többletköltséget jelent, hanem zavar esetén (legyen az véletlen vagy szándékos) a hálózat elégséges müködésének zálogát.

Ezen útvonalak korrekt beazonosítása szükséges a hálózat zavartürő képességének növelését célzó fejlesztésekhez. Ennek érdekében egy absztrakt gráfmodellel írtam le a magyarországi vasúthálózatot és azonosítottam benne azokat a vonalszakaszokat, melyek normál üzemben kevésbé lényeges elemei a hálózatnak, a fővonalak zavara esetén azonban lényeges szerephez juthatnak.

A két legfontosabb ilyen vonalszakasz a 80-as fővonal Nyíregyháza és Miskolc közötti szakasza, illetve a 2-es és 4-es vasútvonalak Almásfüzitő és Angyalföld között, melyek kétvágányúsítása (és utóbbi esetében a megfelelő sebességet lehetővé tevő pálya kiépítése) létfontosságú lenne a hálózat müködőképességének biztosításához a TEN-T hálózati elemek sérülése esetén.

A 2-es és 4-es vonalak támogatására a 77-es és 78-as vonalak (Vácrátót-Galgamácsa-Aszód) fejlesztése is fontos lenne. Ennek célja egyrészt (a megfelelő deltavágányok létesítésével és az Újpesti vasúti híd kétvágányúsításával) az Összekötő vasúti híd számára reális alternatíva biztosítása, másrészt a Budapest Szlovákia felé történő elkerülésének lehetősége. Ehhez azonban ezen vonalaknak megfelelő áteresztőképességgel kell rendelkezniük.

A villamosítás minden esetben kívánatos lenne, de megfelelő méretü dízelmozdony-flotta nélkül a felsővezetékhálózat sérülése önmagában is ellehetetleníti a közlekedést.

A fentiek azonban mind meglévő vasútvonalak fejlesztéséről szólnak. Ez azonban csak az első lépés lehet a magyar vasúti áruszállítás nemzetgazdasági jelentőségének növelésében. Új vasútvonalak építésekor célszerü lenne a bemutatott elvek és módszerek alkalmazása, hogy az új vonalak a hálózat sérülékenységének csökkentését is szolgálják, melyek közül jelenleg a legszükségesebb egy megfelelő kapacitású, Budapestet délről elkerülő vasútvonal (a szükséges Duna-híddal együtt történő) megépítése lenne. Ennek, az úgynevezett V0 vonalnak a megépítése sokáig napirenden volt, de jelenleg úgy tűnik, hogy belátható időn belül sajnos nem fog megvalósulni.

\section{FELHASZNÁLT IRODALOM}

[1] HORVÁTH, A.: A kritikus infrasrtuktúra védelem komplex értelmezésének szükségessége In: HORVÁTH, A. (szerk.): Fejezetek a kritikus infrastruktúra védelemböl; Magyar Hadtudományi Társaság, Budapest, 2013., 18-37. o. (ISBN 9789630869263); mhtt.eu/hadtudomany/KIV_tanulmanykotet.pdf (letöltve: 2019.03.31.)

[2] HORVÁTH, A.: A vasúti közlekedés terrorfenyegetettségének jellemzői a városokban; Hadmérnök IV. 3. (2009) 180-189. o.; hadmernok.hu/2009_3_horvatha.pdf (letöltve: 2019.03.31.) 
[3] HORVÁTH, A.: A közúti, vasúti és vízi közlekedés terrorfenyegetettségének jellemzöi In: TÁLAS P. (szerk.): Válaszok a terrorizmusra II.; Mágustúdió, Budapest, 2006., 321-336. o.

[4] SZÁSZI, G.: A vasúti hálózati infrastruktúrával szemben támasztott újszerü védelmi követelmények kutatása, a továbbfejlesztés feltételrendszerének vizsgálata (Doktori értekezés); Nemzeti Közszolgálati Egyetem, katonai Müszaki Doktori Iskola, Budapest, 2013.

(DOI: 10.17625/NKE.2014.028); uni-nke.hu/downloads/konyvtar/digitgy/phd/2014/szaszi_gabor.pdf (letöltve: 2019.03.31.)

[5] SZÁSZI, G.: A vasúti közlekedési alágazat, mint kritikus infrastruktúra In: HORVÁTH, A. (szerk.): Fejezetek a kritikus infrastruktúra védelemböl; Magyar Hadtudományi Társaság, Budapest, 2013., 167-190. o. (ISBN 9789630869263); mhtt.eu/hadtudomany/KIV_tanulmanykotet.pdf (letöltve: 2019.03.31.)

[6] SZÁSZI, G.: Nagyfolyami vasúti hidak, mint közlekedési létfontosságú rendszerelemek In: HORVÁTH, A.; BÁNYÁSZ, P.; ORBÓK, Á. (szerk.): Fejezetek a létfontosságú közlekedési rendszerelemek védelmének aktuális kérdéseiröl; Nemzeti Közszolgálati Egyetem, Budapest, 2014. 27-46. o. (ISBN 9786155305306)

[7] SZÁSZI, G.: Long-span railway bridges in the transport system of Hungary; Hadmérnök VIII. 2. (2013) 98-107. o.; hadmernok.hu/132_09_szaszig.pdf (letöltve: 2019.03.31.)

[8] HAJNAL, P.: Gráfelmélet; Szegedi Egyetemi Kiadó Polygon, Szeged, 2017. (ISSN 1417-0590)

[9] TÓTH, B.: Állomások és állomásközök zavarának gráfelméleti alapú vizsgálata a magyarországi vasúthálózaton; Hadmérnök XII. 4. (2017) pp. 52-66.; hadmernok.hu/174_06_toth.pdf (letöltve: 2019.03.31.)

[10] TÓTH, B.: Menetidö- és menetvonalhossz növekedés gráfelméleti alapú vizsgálata a magyarországi vasúthálózaton állomások és állomásközök zavara esetén; Hadmérnök XIII. 1. (2018) pp. 118-132.; hadmernok.hu/181_09_toth.pdf (letöltve: 2019.03.31.)

[11] TÓTH, B.: A magyarországi vasúthálózat zavarainak gráfelméleti alapú vizsgálata; In: HORVÁTH, B.; HORVÁTH, G., GAÁL, B. (szerk.): Közlekedéstudományi Konferencia, Széchenyi István Egyetem Közlekedési Tanszék, Győr, 2018., 505-519. o. (ISBN 9786155776137)

[12] F. 2. sz. Forgalmi Utasítás; MÁV ZRt. Pályavasúti Üzletág Forgalmi Főosztály; 22-23. o.; https://www.mavcsoport.hu/sites/default/files/upload/publicprocurement/document/public/f._2._sz._forgalmi_utasitas.pdf (letöltve: 2019.03.31.)

[13] Vasútvonalak http://www.vpe.hu/takt/vonal_lista.php (letöltve: 2019.03.31.)

[14] 277/2014. (XI. 14.) Kormányrendelet a vasúti közlekedési hatóság által kiszabható bírság mértékéröl és megfizetésének részletes szabályairól; https://net.jogtar.hu/jogszabaly?docid=A1400277.KOR (letöltve: 2019.03.31.)

[15] SZÁSZI, G.: A védelmi szempontból meghatározó repülőterek vasúti kapcsolatának helyzete Magyarországon, Repüléstudományi Közlemények (1997-től) XXI. Különszám (2009) 1-22. o.; www.repulestudomany.hu/kulonszamok/2009_cikkek/Szaszi_Gabor.pdf (letöltve: 2019.03.31.)

[16] SZÁSZI, G.: Katonai vasúti szállitások a Magyar Honvédség missziós feladatainak rendszerében; Szolnoki Tudományos Közlemények XIV. (2010) 101-118. o. 
[17] F. 2. sz. Forgalmi Utasitás függelékei, 15. sz. függelék; MÁV ZRt. Pályavasúti Üzletág Forgalmi Főosztály, 101. o.; https://www.mavcsoport.hu/sites/default/files/upload/publicprocurement/document/public/ f._2._sz._forgalmi_utasitas_fuggelekei.pdf (letöltve: 2019.03.31.)

[18] SZÁSZI, G.: Magyarország közlekedési infrastruktúrájának fejlesztése napjainkban: Közút vagy vasút? - Katonai Logisztika 15. 2. (2007) 32-59. o.; http://epa.oszk.hu/02700/02735/00062/pdf/EPA02735_katonai_logisztika_2007_2_032059.pdf (letöltve: 2019.03.31.)

[19] KÁLMÁN, L.: Budapest vasúti közlekedésének fejlesztése - Vasút a Duna alatt (1. rész); Sínek Világa 2011/4, 16-20. o.

[20] LAKATOS, P., SZÁSZI, G, TAKSÁS, B: A logisztikai infrastruktúra szerepe a regionális versenyképesség alakitásában In: CSATH, M. (szerk.): Regionális versenyképességi tanulmányok; NKE Szolgáltató Nonprofit Kft., Budapest, 2016., 181228. o.

[21] SZÁSZI, G.: Transz Európai Közlekedési Hálózat (TEN-T) tervezett fejlesztési iránya, várható hatása Magyarország vasúthálózatának fejlesztésére; Szolnoki Tudományos Közlemények XVI. (2012) 402-425. o.

[22] Trans-European transport network - TEN-T priority axes and projects 2005; European Commission, Office for Official Publications of the European Communities, Luxembourg, $\quad 2005 ., \quad 72 . \quad$ o. $\quad$ (ISBN 9289498374 ); ec.europa.eu/ten/transport/projects/doc/2005_ten_t_en.pdf (letöltve: 2019.03.31.)

[23] SZÁSZI, G.: Jász-Nagykun-Szolnok megye vasúthálózatának védelmi szempontú elemzése; Szolnoki Tudományos Közlemények XIII. (2009) 101-125. o.

[24] SZILY, I.; SZABÓ, L.: Vasúti üzemtan II.; Széchenyi István Egyetem - Universitas-Györ Kht. (Györ), 2006.

[25] ERCSEY, Z.; KISTELEKI, M.; VINCZE, T.: Lassújelek hatásai a vasúti közlekedés költségeire 2. rész; Vasútgépészet 2012/3. 16-19. o.; vasutgepeszet.hu/wpcontent/uploads/2012/09/201203_16-19_vegl.pdf (letöltve: 2019.03.31.)

[26] $R$ Core Team (2012). $R:$ A language and environment for statistical computing. $R$ Foundation for Statistical Computing, Vienna, Austria. ISBN 3-900051-07-0, URL http://www.R-project.org/

[27] CSARDI, G., NEPUSZ, T.: The igraph software package for complex network research, InterJournal, Complex Systems 1695. 2006. http://igraph.org

[28] DIJKSTRA, E. W.: A Note on Two Problems in Connexion with Graphs; Numerische Mathematik I. (1959) 269-271. o. (DOI 10.1007/BF01386390); wwwm3.ma.tum.de/foswiki/pub/MN0506/WebHome/dijkstra.pdf (letöltve: 2019.03.31.)

[29] SCOTT, D. M.; NOVAK, D.; AULTMAN-HALL, L.; GUO, F.: Network Robustness Index: A New Method for Identifying Critical Links and Evaluating the Performance of Transportation Networks, Journal of Transport Geography 14 (3), pp. 215-227 (2006) (DOI: 10.1016/j.jtrangeo.2005.10.003) 
[30] JENELIUS, E.: Redundancy importance: Links as rerouting alternatives during road network disruptions, Procedia Engineering 3, pp. 129-137 (2010) (DOI: 10.1016/j.proeng.2010.07.013);

https://www.sciencedirect.com/science/article/pii/S1877705810004820/pdf?md5=6fef0 129a7646468761bad5506b12aab\&pid=1-s2.0-S1877705810004820-main.pdf (letöltve: 2019.03.31.)

[31] ENDRÖDI, I.: A közlekedési ágazat kritikus infrastruktúra elemei, kapcsolatuk a katasztrófavédelemmel, figyelemmel az Európai Unió Kritikus Infrastruktúrák Azonositásáról és Kijelöléséröl szóló 2008. évi 2008/114/EK Tanácsi Irányelvében megfogalmazottakra In: HORVÁTH, A. (szerk.): Fejezetek a kritikus infrastruktúra védelemböl; Magyar Hadtudományi Társaság, Budapest, 2013., 238-267. o. (ISBN 9789630869263); mhtt.eu/hadtudomany/KIV_tanulmanykotet.pdf (letöltve: 2019.03.31.) 